\title{
A COMIDA E O COMER DURANTE O JUBILEU DE SÃO MIGUEL E ALMAS NO CEMITÉRIO DO PEIXE
}

\author{
Thiago Rodrigues Tavares ${ }^{1}$ \\ Vanessa Gomes de Castro ${ }^{2}$
}

\section{Introdução}

O presente trabalho busca descrever e analisar aspectos relacionados à comida e ao ato de comer, durante o Jubileu de São Miguel e Almas, que acontece no Cemitério do Peixe, vilarejo pertencente à cidade de Conceição do Mato Dentro, Minas Gerais. Para tanto, utilizam-se métodos e caminhos propostos pela Antropologia, no desenvolvimento da pesquisa. Assim, vivenciamos no tempo presente os acontecimentos da Festa, como observadores participantes, entre os anos de 2012 a 2019, buscando empreender uma pesquisa etnográfica. Ao longo desse período, além da observação e participação, foram realizadas entrevistas abertas e semiestruturadas com os frequentadores do Jubileu ${ }^{3}$. Desta forma, busca-se compreender a alimentação enquanto um fenômeno relacionado à cultura, o qual estabelece e reforça as identidades, as sociabilidades, as memórias e os patrimônios dos grupos participantes. Como observa Da Matta (1986), alimento é tudo aquilo que pode ser ingerido para manter uma pessoa viva; comida é tudo que se come com prazer, de acordo com as regras mais sagradas da comunhão e comensalidade.

Conforme apontado por Mintz (2001), desde o seu início, a Antropologia demonstrou grande interesse pela comida e pelo ato de comer, isto é, a maneira que se come, o quê, onde, como, com que frequência se come e como nos sentimos em relação à comida. Logo, comidas cotidianas e prosaicas, que tendemos a considerar comuns, escondem histórias e fatos sociais, culturais, políticos e econômicos complexos, atuando no cerne da organização da vida social (MINTZ, 2001).

Contreras e Gracia (2015) destacam que, especialmente a partir da década de 1980, se intensificaram os esforços teóricos e metodológicos para se definir uma

\footnotetext{
${ }^{1}$ Universidade Federal de Juiz de Fora, Brasil. Email: thiagor.tavares@yahoo.com.br ORCID id: https://orcid.org/0000-0002-5798-4325

${ }^{2}$ Universidade Federal de Juiz de Fora, Brasil. Email: vadecastro@hotmail.com ORCID id: https://orcid.org/0000-0002-8281-4491

${ }^{3}$ Esse trabalho é um desdobramento da pesquisa de doutorado que vem sendo desenvolvida no Programa de Pós-graduação em História, da Universidade Federal de Juiz de Fora, financiada em diferentes momentos pelas agências de fomento FAPEMIG e CAPES.
}

Iluminuras, Porto Alegre, v. 20, n. 51, p. 323-347, dezembro, 2019. 
"Antropologia da Alimentação", enquanto campo de estudos cujos conceitos e métodos se apoiam em diferentes tradições teóricas e metodológicas da Antropologia. Desta forma, a "Antropologia da Alimentação" passou a se debruçar sobre o estudo da “cultura alimentar", isto é, o conjunto de representações, significados, crenças, rituais, conhecimentos e práticas associadas à alimentação, herdadas e aprendidas de geração para geração, sendo compartilhadas por indivíduos de uma dada cultura ou grupo social (CONTRERAS; GRACIA, 2015).

No Brasil, os viajantes, os folcloristas, os cronistas e os romancistas, por exemplo, foram os primeiros a descreverem a alimentação enquanto um aspecto da cultura local, que mescla o indígena, o colonizador e os escravizados. A partir da década de 1930/1940 e, sobretudo, dos anos 1950/1960 em diante, com a configuração e o fortalecimento das universidades e institutos de pesquisas no país, bem como o fortalecimento da Antropologia Brasileira enquanto campo de conhecimento científico, que a relação entre a cultura e as práticas alimentares foi se alicerçando como uma área específica de investigações dentro desse campo (CANESQUI, 2005).

Assim, na Antropologia Brasileira, no que se refere à alimentação, ao longo do século XX, destacam-se os estudos sobre as fontes de abastecimento e produção alimentar; economia de subsistência ou extrativista; símbolos, práticas, crenças e tabus associados à alimentação; composição da dieta e preparo dos alimentos; regionalismos culinários; comida e identidade; cozinha e religião; a importância feminina no preparo alimentar; a comercialização dos alimentos; fast-food e a reorganização da comensalidade na sociedade urbano-industrial. Ressaltam-se os trabalhos de Gilberto Freyre, Josué de Castro, Antônio Cândido, Câmara Cascudo, além dos estudos de Otávio Velho, Mariza Peirano, Ana Maria Canesqui, Carlos Rodrigues Brandão, Roberto Da Matta, dentre outros (CANESQUI, 1988; 2005).

$\mathrm{Na}$ contemporaneidade, a relação entre alimentação, sociedade e cultura tem se consolidado como objeto de análise, em suas mais diversas dimensões, com distintas abordagens teóricas e empíricas, seja na Antropologia, ou em outros campos de conhecimento (CONTRERAS E GARCIA, 2015). Diante disso, visando contribuir com as pesquisas na área da "Antropologia da Alimentação", o presente trabalho busca descrever e analisar aspectos relacionados à comida e ao de comer, durante os dias do Jubileu de São Miguel e Almas no Cemitério do Peixe (MG), por meio da observação 
participante e da realização de entrevistas abertas e semiestruturadas com os frequentadores da Festa.

\section{Contexto histórico do Jubileu de São Miguel e Almas no Cemitério do Peixe}

Durante o mês de agosto, no vilarejo do Cemitério do Peixe, acontece o Jubileu de São Miguel e Almas. O vilarejo está localizado no centro-norte do estado de Minas Gerais, na Serra do Espinhaço, às margens do Rio Paraúna, pertencendo à cidade de Conceição do Mato Dentro. Atualmente, o pequeno vilarejo é formado por cerca de duzentas casas, a igreja de São Miguel Arcanjo e o cemitério. O lugar se destaca por nunca ter sido habitado constantemente, mantendo-se vazio durante a maior parte do ano. Logo, é chamado por alguns de "cidade-fantasma". Na verdade, o vilarejo apresenta características singulares. As edificações, por exemplo, foram construídas posteriormente ao Cemitério, com o objetivo de receber os devotos das Almas do lugar. Assim, o status de "cidade-fantasma" se modifica em algumas oportunidades ao longo do ano, sendo que a principal transformação ocorre em torno do dia 15 de agosto, quando o local recebe milhares de pessoas dentre romeiros, turistas, festeiros e comerciantes, que vão celebrar e festejar o Jubileu de São Miguel e Almas.

O Cemitério teria surgido no período da intensa exploração de diamantes, que ocorreu ao longo dos séculos XVIII e XIX, em Minas Gerais. O lugar estava nas imediações do Distrito Diamantino, uma ordem administrativa e territorial, especialmente criada pela Coroa Portuguesa, originalmente demarcada em 1734, sendo ampliada em 1739, 1753 e 1757, com o intuito de controlar a exploração de diamantes (CARRARA, 2017). Nos mitos narrados pelos frequentadores sobre o surgimento do lugar, destacam-se três personagens principais: soldados, escravos e peixes. Segundo um dos mitos, naquele lugar, existia um quartel com o objetivo de impedir o contrabando de diamantes. Os soldados que ali estavam, muitas vezes, alimentavam-se de peixes pescados no Rio Paraúna. Porém, em um determinado momento, esses soldados consumiram peixes estragados, vindo a morrer. Como é um local isolado, esses soldados foram enterrados por ali mesmo, culminando no Cemitério do Peixe. Outro mito conta a história de um escravo, cujo nome era Peixe, o qual foi encontrado morto naquele lugar, sendo enterrado por ali mesmo, dando origem ao Cemitério do Peixe. Esses mitos desencadeiam diversas versões e histórias. Contudo, o peixe está 
sempre presente, seja como alimento ou como nome/apelido de escravizados ou soldados.

As estradas que circundam as imediações do vilarejo do Cemitério do Peixe foram rotas de diversas pessoas durante o período colonial: fazendeiros, garimpeiros, tropeiros, indígenas, escravizados e quilombolas passaram por ali. Observa-se que o lugar não foi habitado constantemente durante o período colonial, entretanto, seu terreno estava próximo aos quartéis de fiscalização da Coroa Portuguesa, cercado por fazendas escravocratas e por indivíduos garimpando nas águas do Rio Paraúna. Evidencia-se que, durante esse período, as pessoas ainda não tinham local adequado para serem enterradas, principalmente, os negros e os mais pobres. Nesse processo, o lugar passou a receber os mortos da região, formando o Cemitério do Peixe.

Assim, as pessoas começaram a cultuar os enterrados ali e também a realizar um momento de festividade e devoção às Almas do lugar. Até o momento, um dos registros mais antigos encontrados sobre o Cemitério do Peixe é uma notícia publicada na edição 40, do jornal O Jequitinhonha, de Diamantina, Minas Gerais, na seção Publicações à Pedido, do dia 16/11/1861, na página 04 , onde consta que o vilarejo reúne sazonalmente muitas pessoas em busca de oração, comércio, festa, jogos, bebidas e divertimento, pelo menos, desde meados do século XIX (TAVARES, 2018).

Antes de narrar o que observei no dia 15 de agosto de 1861, no lugar denominado - Cemitério do Quartel do Peixe, - é mistério da origem da devoção que nesse dia ahi se faz(...)Na vespera do dia 15 de Agosto diferentes negociantes vão para esse lugar, é entorno do cercado do cemitério, em torno mesmo da Ermida elevão seus cazebres momentaneos, tornando assim, esse dia 15 uma verdadeira feira, ou melhor, um bachanal pela profusão de licores, ahi se bebe ao ponto de reunidas contendas, como já as tem havido, que chegão a ferirem-se uns aos outros, poucas são as pessoas que dotadas de um espírito verdadeiramente religiozo, meditão nesse quadro cercado e defendido pelo Estandarte da Religião ahi arvorado, onde habitão para sempre esses corpos outr'ora vivificados; talvez, de mil a mil e tantas pessoas, que nesse dia ahi se ajuntão só a $3^{\mathrm{a}}$ parte irá cumprir o preceito da Missa e dar de coração a essas almas (...) O respeito devido aos mortos é ahi interrompido, porque mesmo dentro do cercado girão taboleiros de sequillos, garrafas pejadas de differentes bebidas, ditos não próprios do lugar e só próprios da mais furioza bachanal $(\mathrm{O}$ Callado Observador, Jornal O Jequitinhonha, 1861: 4) ${ }^{4}$

\footnotetext{
${ }^{4}$ O Callado Observador é o pseudônimo utilizado por quem escreveu o artigo. Observa-se que o autor escreve com um pensamento típico de sua época, fomentado por uma ação romanizadora praticada pela Igreja Católica.
} 
O lugar de sepultamentos, que se inicia no período colonial, sendo sacralizado pela população ao longo do século XIX, adquire novos contornos no início do século seguinte. Nas primeiras décadas do século XX, a organização e controle do espaço ocorreram através da ação de Antônio Francisco Pinto (1860-1941), conhecido por “Canequinha”. Após herdar a fazenda do Vassalo, onde está situado o Cemitério do Peixe, e se consolidar como grande fazendeiro da região, "Canequinha" decidiu demonstrar sua religiosidade para com as almas e, possivelmente, controlar aquela aglomeração que acontecia no lugar. Desse modo, construiu a Igreja de São Miguel, a Casa Paroquial e a Casa dos Romeiros. Em seguida, conseguiu colocar o Cemitério do Peixe na rota das missões redentoristas.

A chegada dos missionários redentoristas ao Cemitério do Peixe ocorreu no período de intensificação do processo de romanização no Brasil. A romanização foi uma reforma católica que visava implantar um mesmo modelo de catolicismo em todos os lugares, definindo-se pela centralização da religião em torno de Roma, além da erradicação de catolicismos locais considerados supersticiosos e fanáticos. A Congregação do Santíssimo Redentor, comumente chamada de Congregação Redentorista, foi fundada por Santo Afonso Maria de Ligório, em 1732, na Itália, dedicando suas funções à evangelização dos mais pobres, através das missões. Em 1893, os primeiros padres redentoristas, de nacionalidade holandesa, chegaram ao Brasil e fixaram-se em Minas Gerais, realizando missões na região central e norte do Estado. No ano de 1916, foi registrada no Livro de Provisões do Bispado de Diamantina, a autorização para a realização das missões no Cemitério do Peixe.

As missões redentoristas no Cemitério do Peixe foram objeto de estudo de Tavares (2018), por meio de notícias publicadas no início do século XX, pelos jornais diamantinenses (MG): O Pão de Santo Antônio, Voz de Diamantina e A Estrella Polar. Observa-se que as missões redentoristas tiveram grande importância e êxito e na realização do Jubileu. Durante praticamente toda a primeira metade do século XX, os padres redentoristas realizaram no lugar missas, confissões, procissões, batismos, crismas e casamentos. Levando, desse modo, os sacramentos da Igreja aos grupos isolados e reunindo milhares de pessoas.

Nesse contexto, a festa passou a se chamar Jubileu de São Miguel e Almas. Todavia, apesar da devoção a São Miguel Arcanjo, tudo indica que a fé das pessoas 
sempre esteve ligada às Almas do Peixe. Tanto que, "Canequinha", então dono do terreno onde está situado o Cemitério, no ano de 1940, um ano antes da sua morte, doou em cartório todo o terreno do Cemitério do Peixe para as Almas enterradas no lugar ${ }^{5}$.

Com o desenvolvimento da festa religiosa em torno do Cemitério do Peixe, os romeiros passaram a acampar e mesmo a construir pequenas casas para servirem de apoio durante as festividades. Desde o falecimento de "Canequinha" e com a doação do terreno para as Almas, quem passou a administrar o lugar foram os próprios devotos, juntamente com a Igreja Católica. Assim, o Cemitério do Peixe também é um lugar de disputas e conflitos, sendo que algumas pessoas detêm mais poder do que outras. Os romeiros que desejam construir para usufruto uma pequena casa no Cemitério do Peixe precisam da autorização destes administradores (embora, em alguns casos, isso não seja respeitado). Assim, as casas são de usufruto dos devotos, pois o espaço onde se encontra o Cemitério foi doado em cartório pelo proprietário às Almas. Logo, as casas, desde sempre, servem apenas como abrigos temporários, nesse lugar de passagem e romaria sazonal.

O Jubileu de São Miguel e Almas, que acontece no vilarejo do Cemitério do Peixe (MG), apresenta características fundamentais da vivência popular do catolicismo, da devoção ao santo e às almas, da romaria, da festa e da variedade de cultos, tanto domésticos quanto coletivos. A peregrinação começa no início da semana com a chegada dos padres e dos moradores da região, intensificando-se no final de semana com romeiros vindos de diversos lugares. De quarta-feira até domingo, cerca de cinco mil pessoas passam pelo vilarejo, estabelecendo uma espécie de communitas, já que a vida cotidiana é interrompida por um momento e uma nova vida é criada durante o festejo para as Almas. De acordo com Turner (2008), a vida social se desloca a partir de um movimento dialético, o qual envolve a estrutura social e a communitas - estrutura e antiestrutura. Segundo o antropólogo, a estrutura (vida cotidiana) possibilita a antiestrutura (momentos excepcionais), na medida em que a sociedade, ao lidar com suas crises, estabelece as communitas, períodos liminares, instituídos pela própria sociedade, visando lidar com as suas contradições, conflitos e crises.

Durante os dias de Jubileu, destacam-se momentos de peregrinação, sociabilidade e trocas materiais e simbólicas entre os frequentadores. Segundo Ingold

\footnotetext{
${ }^{5}$ Cartório de Registro de Imóveis de Conceição do Mato Dentro (MG), livro 3-G de transcrição das transmissões, folhas 153 verso/154, registro n² 2573 de 28/05/1940.
}

Iluminuras, Porto Alegre, v. 20, n. 51, p. 323-347, dezembro, 2019. 
(2015), os seres humanos habitam a terra enquanto peregrinos. O peregrinar é o modo mais fundamental de estar no mundo. A peregrinação é o termo utilizado para descrever a experiência corporificada do movimento de perambulação. Logo, o peregrino está em constante movimento, ou melhor, ele é o movimento. Durante o movimento, ao longo do caminho, cada habitante deixa uma trilha. Nos locais onde os habitantes se encontram, as trilhas são entrelaçadas, ao mesmo tempo em que a vida de cada um vincula-se à do outro. De acordo com Ingold (2015), cada entrelaçamento é um nó e, quanto mais linhas são entrelaçadas, maior é a densidade desses nós. "Lugares, então, são como nós, e os fios a partir dos quais são atados são linhas de peregrinação" (INGOLD, 2015: 220).

Os momentos de peregrinação, sociabilidades e trocas, acontecem nos ambientes entre o cemitério e a igreja de São Miguel Arcanjo, que são lugares em que as pessoas demonstram sua fé e realizam suas celebrações. Tudo que se refere à parte sagrada, como a alvorada, as missas, a chegada dos cavaleiros, as bênçãos e as procissões, é realizado entre a igreja de São Miguel e o cemitério. Todavia, durante os dias de Festa, os frequentadores transitam constantemente por diferentes ambientes. As casas também são lugares de sociabilidades, congregando parentes e amigos: as pessoas conversam, brincam, cantam, jogam, comem e bebem. O Cemitério passa a ser o ponto de chegada, tornando-se um núcleo de encontro.

Durante a Festa um dos principais locais de interação social é a Rua do Fogo ${ }^{6}$, ambiente profano contraposto ao sagrado da Festa - missas e procissões. A Rua do Fogo é o lugar onde se concentram bares, barraquinhas de comida, comércio de diversos tipos de objetos, assim como brincadeiras e jogos, por exemplo, pula-pula, tiro ao alvo e baralho. Essa rua permanece movimentada durante todos os dias de Jubileu. Há muita bebida, comida e músicas como funk, axé e sertanejo, surgindo de dentro das barraquinhas, ou mesmo de carros com grande potencial de som. As músicas são dançadas por grupos de pessoas de todas as idades. $\mathrm{O}$ clima de paquera domina o ambiente. Muitas pessoas vão para o Jubileu de São Miguel e Almas no Cemitério do Peixe apenas para aproveitar a Rua do Fogo, espaço que, para alguns, destoa da festa religiosa. Além disso, outro lugar profano cercado por tabus e lendas é a "beira do rio"

\footnotetext{
${ }^{6}$ Segundo Richard Burton, viajante e diplomata britânico, que esteve no Brasil em meados do século XIX. Rua do Fogo não era um nome raro nas cidades do Brasil, para indicar que nela as bebidas e, consequentemente, os conflitos abundam (BURTON, 1983, p.278).
} 
(margem do Rio Paraúna, onde se situa o Vilarejo Cemitério do Peixe). Segundo os frequentadores é um ambiente que, historicamente, por ser mais afastado das áreas de maior circulação de pessoas, era (e continua sendo) utilizado para buscar água, tomar banho, utilizar a mata ao redor para fazer as necessidades fisiológicas e ter relações sexuais.

Conforme destaca Perez (2002), a festa não é um simples produto da vida social, mas o próprio ato de produção da vida. É um evento marcante na construção da vida em sociedade. Sua ocorrência se opõe ao ritmo regular e rotineiro do cotidiano. Independente se é uma festa religiosa ou uma festa profana, o que importa é que ela é um lugar privilegiado de reunião das diferenças e de construções sociais, espaço primordial para a formação de uma assembleia coletiva e de sociabilidade.

\section{A comida e o ato de comer durante o Jubileu}

A festa do Cemitério do Peixe tem quatro dias de duração. No lugar, alguns devotos usufruem de uma pequena casinha de dois ou três cômodos, muitas sem cozinha e banheiro, não possuindo energia elétrica e água encanada - embora, atualmente, isso esteja mudando. Muitas dessas casas foram construídas com tijolos de adobe, contudo, ao longo dos anos, mudaram-se as técnicas e os materiais empregados para a construção. Nos dias de hoje, assim como foi no passado, quando esses devotos vão participar da Festa, precisam levar consigo todo o necessário para a subsistência, desde comida (incluindo condimentos, açúcar, sal, banha, óleo, pimenta, gás, lenha, carvão etc.), utensílios de cozinha (prato, panela, talher, copo, vassoura, garrafa de café etc.), roupas de cama (colchão, travesseiros e cobertores), objetos e produtos de uso pessoal (como sabonete, toalhas, roupas). Tudo isso, sendo transportado com muita dificuldade, pois é um lugar de difícil acesso. Diversas pessoas utilizam transportes de tração animal, como cavalos e carros de boi.

Além disso, os devotos, principalmente aqueles que moram na mesma comunidade, costumam fretar coletivamente um caminhão ou caminhonete para levar e buscar os seus pertences. Muitos dos devotos, sobretudo aqueles que moram em comunidades vizinhas, também vão para o Cemitério do Peixe a pé, passando por trilhas, tendo que atravessar o rio que corta essas localidades, com suas sacolas na 
cabeça, homens, mulheres e crianças, de todas as idades. Essa prática de peregrinação é uma tradição que se mantém há mais de um século. Muitos dos frequentadores do Peixe continuam a reproduzir as práticas de seus pais e avós.

Quanto ao armazenamento, muitas dessas casas não possuem mobiliário fixo, como armários e geladeira. Os alimentos não perecíveis ficam guardados em latas, sacolas, vasilhas, garrafas, caixas, caixotes, etc. Por outro lado, algumas poucas casas possuem equipamentos permanentes em termos de cama, mesa e banho, dispondo de água encanada e energia elétrica, armário e geladeira. Nesse sentido, nota-se que os conhecimentos tradicionais são fundamentais na conservação dos alimentos.

Durante o Jubileu de São Miguel e Almas, muitos devotos costumam chegar na quarta-feira, o primeiro dia de Festa, trazendo a comida e os utensílios básicos para subsistência ao longo dos dias. Ao chegar, esses devotos realizam uma limpeza em suas casas, preparando-as para receber os parentes e amigos que não podem ir todos os dias do Jubileu, pois muitos trabalham ou moram em outra cidade, participando somente do auge do evento, isto é, sábado à noite e domingo pela manhã. O Jubileu é um momento de sociabilidade, de encontro entre família e amigos. Sendo assim, o melhor cardápio (a melhor carne, o churrasco, a mistura diferenciada, a sobremesa) são preparados principalmente no sábado e domingo. Assim, os devotos que chegam no primeiro dia, organizam a casa e guardam a "melhor comida" para o fim de semana.

No que tange ao café da manhã, encontram-se comidas típicas da cozinha mineira, como café, queijo, bolo, biscoitos caseiros, broa de fubá, Kobu (especiaria regional que será abordada mais adiante), pão de queijo e leite. No entanto, conforme mencionado, de acordo com o grupo, por exemplo, aqueles que vão para a parte profana da Festa, o café da manhã pode ser, até mesmo, um salgado, como coxinha, rissole, pastel, dentre outros, comercializados nas barracas.

Em relação ao almoço, de modo geral, servem-se comidas como arroz, feijão, feijão com farinha, feijão tropeiro, frango, carne de porco, torresmo, peixe, churrasco, carne de caça (como Mocó e Paca, espécies de roedores), caldo de mandioca, milhoverde, couve, alface, tomate, dentre outros - como podemos ver nas figuras 01 e 02.

O consumo e o tipo de preparo alimentar dependem da situação dos grupos. No caso dos devotos e seus familiares cujas pequenas casas possuem estrutura precária, muitas vezes recorre-se aos conhecimentos tradicionais para prolongar a durabilidade 
dos alimentos, por exemplo, o peixe defumado em cima do fogão à lenha e a carne de porco na lata com banha. De modo geral, em todas as casas, quando se tem sobremesa, essas incluem principalmente doce de leite e doces de frutas (goiabada; mamão etc.).

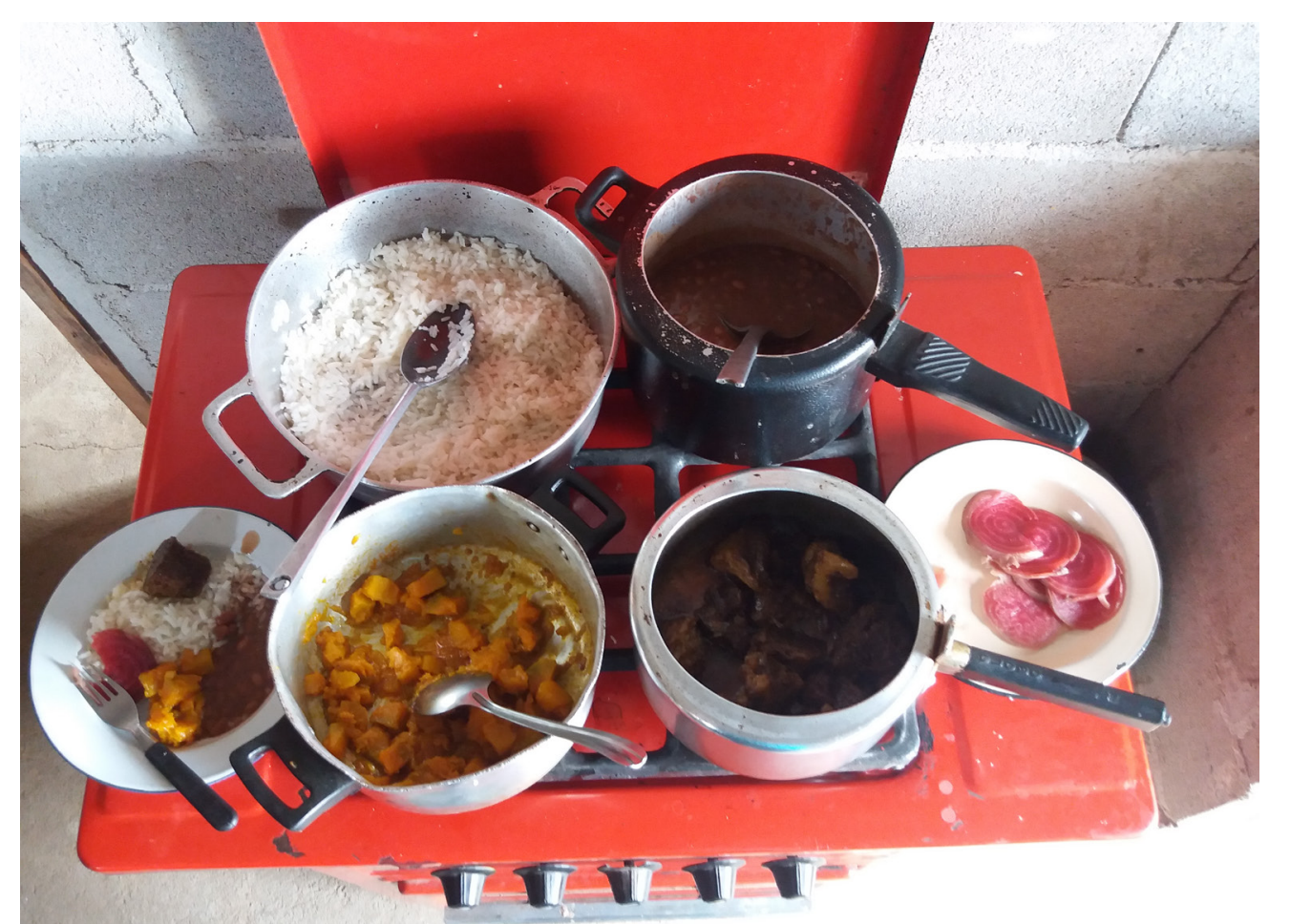

Figura 01 - Almoço servido na casa de uma família de devotos (arroz, feijão, abóbora moranga, carne bovina cozida e beterraba), Cemitério do Peixe. Fonte: Fotografia do autor (18/08/2018)

Dentre os romeiros acampados, costumam-se fazer churrascos, seja em churrasqueiras improvisadas usando roda de caminhão, tijolos ou pedras, ou mesmo, churrasqueiras portáteis. Os romeiros acampados também costumam consumir nas barracas. Já dentre os romeiros que vão para participar somente um dia de Festa, o comércio alimentício nas barracas e a boa vontade de amigos e parentes, que oferecem generosamente um prato de comida, são opções. Além disso, para os romeiros que participam somente no último dia de Festa, o domingo, uma das opções é o almoço servido na Casa dos Romeiros. Esse almoço é organizado e preparado pela Igreja Católica e conta com o ajuda dos devotos. No ano de 2018, quem auxiliou no preparo e na venda do almoço foi o grupo "Encontro de Casais com Cristo" da Paróquia Santo Antônio de Gouveia. Com o valor de dez reais (preço que varia a cada ano), o pratofeito foi servido com arroz, alface, vinagrete, batata e frango.

Iluminuras, Porto Alegre, v. 20, n. 51, p. 323-347, dezembro, 2019. 
No que diz respeito ao jantar, em termos de alimentos, não varia muito em relação ao almoço. No entanto, nessa refeição noturna, muitas pessoas acabam consumindo nas barracas, concentradas na Rua do Fogo, onde grande parte do comércio de alimentos é realizado, tais como a venda de churrasquinhos, caldos, feijão tropeiro, salgados, cachorro-quente, hambúrguer, mini-pizza, pastel, doces (cocadas, bombons, pirulitos coloridos, sorvete, picolé, algodão doce, maçã do amor, churros), pipoca, açaí etc.

O modo como às pessoas se relacionam e se alimentam durante o Jubileu de São Miguel e Almas no Cemitério do Peixe, nos remete ao que foi destacado por Bakhtin (2010). Para o autor, os atos de comer e beber estão justamente relacionados às formas da festa popular. O banquete é uma peça fundamental para a felicidade popular. O triunfo do banquete é universal. O comer ou beber não são atos da vida privada, mas, sim, acontecimentos sociais. Segundo Bakhtin (2010), misturam-se organicamente às noções de vida, morte, renascimento e renovação, além das ideias de verdade, liberdade e felicidade. O banquete e suas imagens reafirmam a verdade, a alegria e a coletividade.

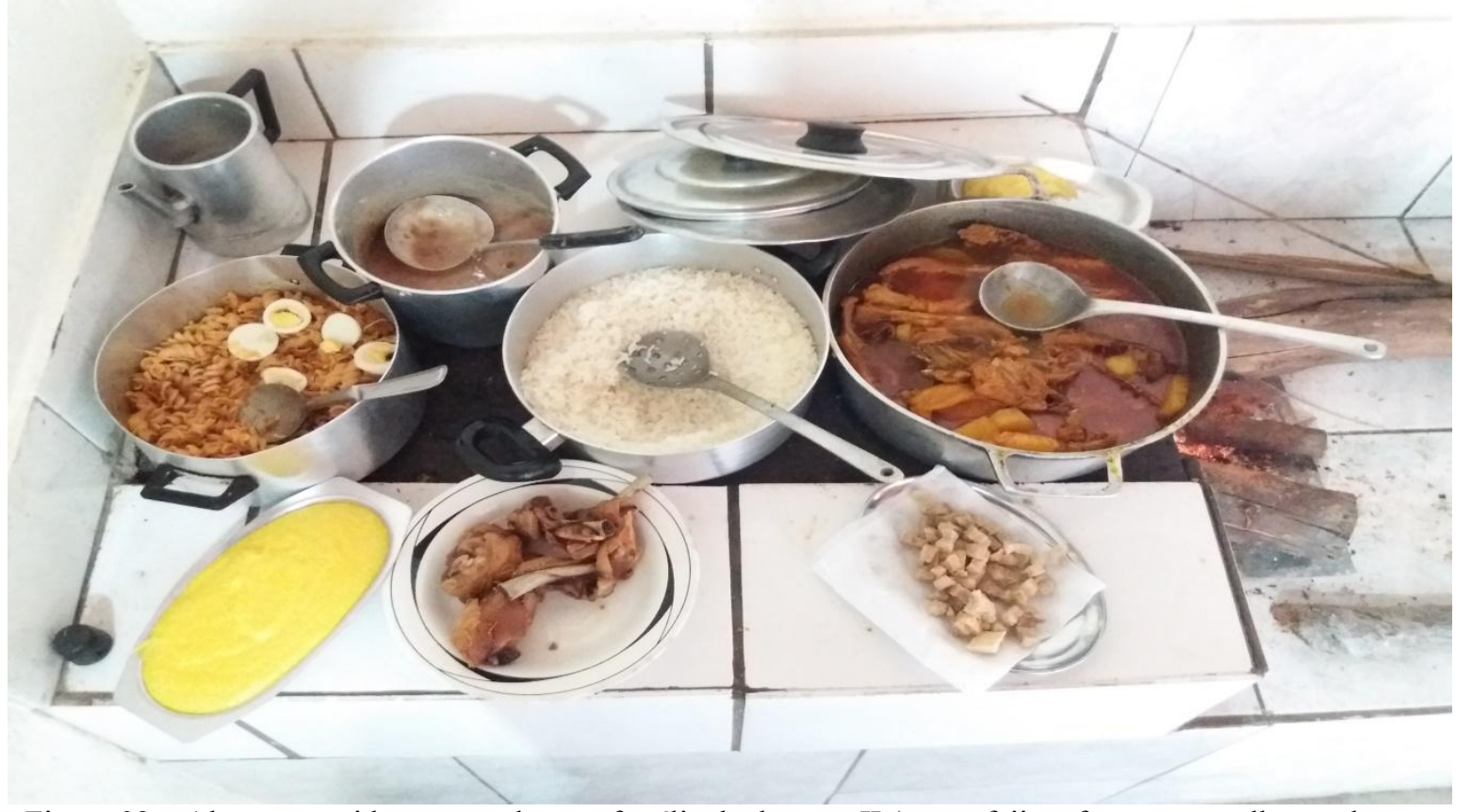

Figura 02 - Almoço servido na casa de uma família de devotos II (arroz, feijão, frango ao molho pardo, frango frito, torresmo, macarrão e angu), Cemitério do Peixe. Fonte: Fotografia do autor (17/08/2018)

Assim, a questão de servir o alimento para amigos e parentes que chegam à sua casa é um hábito do meio rural. Essa hospitalidade pode ser interpretada como uma

Iluminuras, Porto Alegre, v. 20, n. 51, p. 323-347, dezembro, 2019. 
relação de dádiva entre as pessoas. No que tange ao estado de Minas Gerais, desde o século XIX, diversos viajantes relataram o hábito de servir comida como uma marca da hospitalidade dos mineiros. No decorrer do século XX, uma série de crônicas, poemas, músicas, livros de receitas e ensaios sobre a comida mineira continuaram a reproduzir essa imagem (BONOMO, 2013). Ressalta-se, ainda, que nas últimas décadas, tanto em Minas Gerais, quanto no Brasil, os poderes públicos têm empreendido esforços no sentido de promover a culinária regional como um bem cultural, associado à identidade de seus habitantes.

Conforme observado por Dutra (2015), as populações rurais do interior de Minas Gerais, estabelecem uma forte integração com o ecossistema em que vivem por meio dos saberes, os quais os orientam na elaboração de seus alimentos. Segundo a autora, as práticas alimentares, produtos do processo histórico e cultural das comunidades rurais, estão intimamente vinculadas ao contexto ambiental de sua produção. Além do mais, no cenário de hospitalidade mineiro, o principal ponto de fluxo na vida cotidiana doméstica se dá na cozinha. Esse lugar, que é o âmago da casa, ocupa posição de evidência no estabelecimento das interações: acolhe parentes, "compadres" e conhecidos, com a mesa farta e tempo para conversa. Segundo a autora, o ato de "Receber" implica inevitavelmente em cuidar e alimentar, ações primordiais na dinâmica das relações de reciprocidade comunitária presente no mundo rural e na cidade pequena.

Em relação às bebidas, especialmente às bebidas alcoólicas, aparentemente, sempre estiveram presentes na Festa. Nesse sentido, a principal bebida consumida é a cachaça, muito presente no meio rural. A cachaça pode ser encontrada na maioria das casas, desde as mais simples. Bebidas como a cerveja, também são consumidas e comercializadas, principalmente nas barracas, assim como, licores, coquetéis e destilados de diferentes espécies. As bebidas alcoólicas fazem-se presentes desde os primeiros relatos sobre a Festa. Em 1861, por exemplo, já se observava a "profusão de licores que ali se bebia". Segundo o Livro Tombo da Paróquia de Gouveia, no ano de 1976: "neste ano houve um sucesso no Peixe. Bailes, barracas da Brahma, um cabaré organizado por elementos de Curvelo".

Quanto às receitas, chama-se a atenção para o Kobu (figura 03), uma receita típica da região, cuja origem remete à Maria da Gouveia (fundadora da cidade de Gouveia/MG, situada próxima ao Cemitério do Peixe) e seus escravizados. Lembra algo 
como uma broa de fubá, com queijo, enrolada em uma folha de bananeira. O Kobu pode ser considerado um patrimônio da região.

É fácil. Primeiro, coloco a abóbora, bato no liquidificador, misturo no fubá e vai misturando, aí vem com pó Royal, açúcar, queijo, leva uns 04 ou 05 ovos (o tanto do fubá), bate o ovo junto com abóbora, açúcar, canela, isso aí e vai misturando e põem o queijo (minas curado). Eu faço com abóbora, eu gosto porque ele fica bem macio, não fica quebrando. Depois põem no forno bem quentinho (Angela Maria. vilarejo do Cemitério do Peixe, entrevista concedida em 19/08/2017).

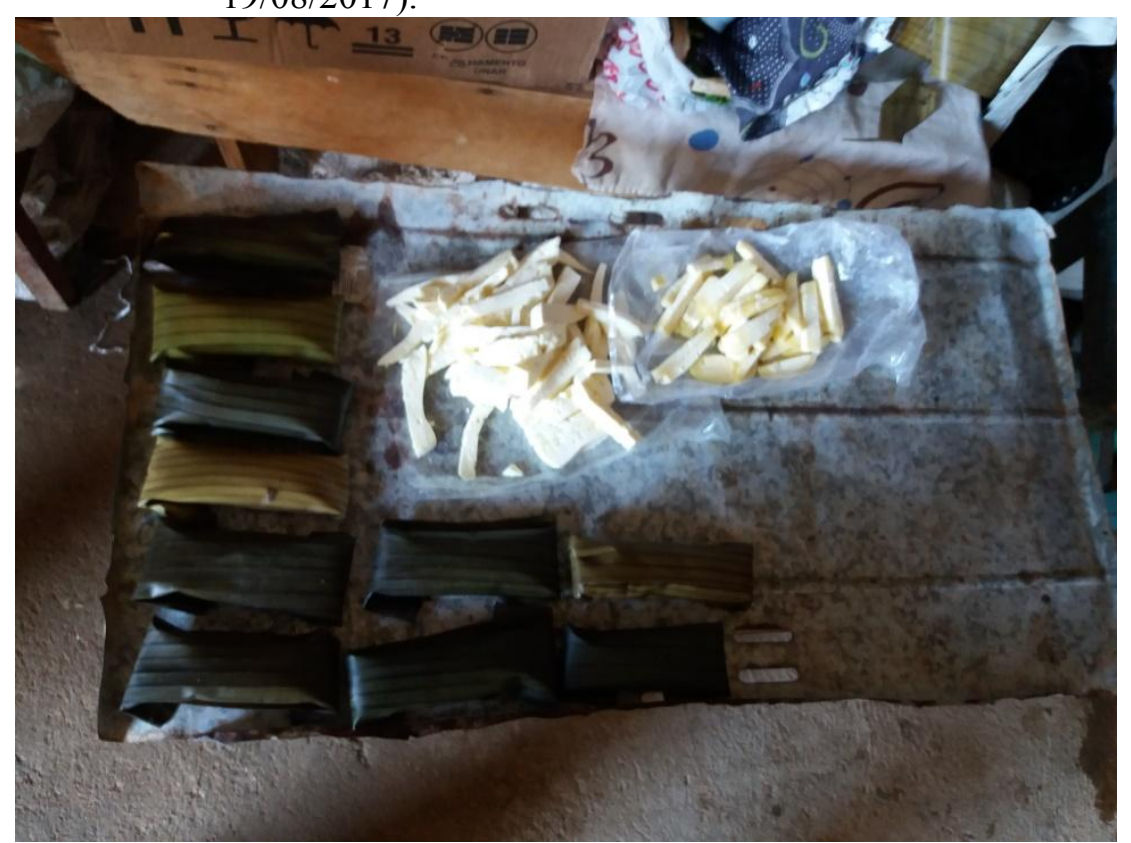

Figura 03 - Kobu, Cemitério do Peixe. Fonte: Fotografia do autor (19/08/2017)

Enquanto nos contava sobre a receita do Kobu, três filhas de Ângela Maria observavam atentamente e ajudavam a mãe na produção e comercialização da iguaria. Como bem observa Mintz (2001), a transmissão geracional de conhecimentos tradicionais através da alimentação é um ponto fundamental, por exemplo, o aprendizado de requinte pessoal, de destreza manual, de receitas, cooperação e compartilhamento, restrição e reciprocidade, atribuídos à socialização alimentar (MINTZ, 2001).

Como afirma Abdala (2006), em Minas Gerais, nas últimas décadas, temos observado a intensificação de movimentos em prol da preservação do patrimônio cultural, bem como do reconhecimento e documentação das tradições culinárias mineiras, como importantes elementos que reforçam a identidade, a imagem do estado e o desenvolvimento econômico. Nesse sentido, destacam-se diversos pratos que se

Iluminuras, Porto Alegre, v. 20, n. 51, p. 323-347, dezembro, 2019. 
tornaram ícones da culinária mineira, isto é, da "cozinha tradicional e típica", a qual compreende saberes, práticas e modos de fazer, abrangendo experiências e memórias, que acompanham a dinâmica social, conservando alguns aspectos ao longo do tempo, mas, também, sofrendo mudanças e adaptações para que continuem a ter sentido para os grupos sociais que as vivenciam no presente.

Falando em tradição, destaca-se, inclusive, o fogão à lenha, peça central das cozinhas rurais. É no fogão à lenha que os alimentos são cozidos, fritos e defumados. Muitas das casas possuem um fogão à lenha, que também é responsável por mantê-las aquecidas, já que as noites no Cemitério do Peixe são muito frias. Como nem todas as casas possuem cozinha, em alguns casos são improvisados fogões ao ar livre, utilizando amontoados de pedras e outros materiais. Algumas casas também contam com um forno de tijolo ou barro em seu exterior, onde são assados Kobu, biscoitos e pães de queijo, como pode ser visto na figura 04 .

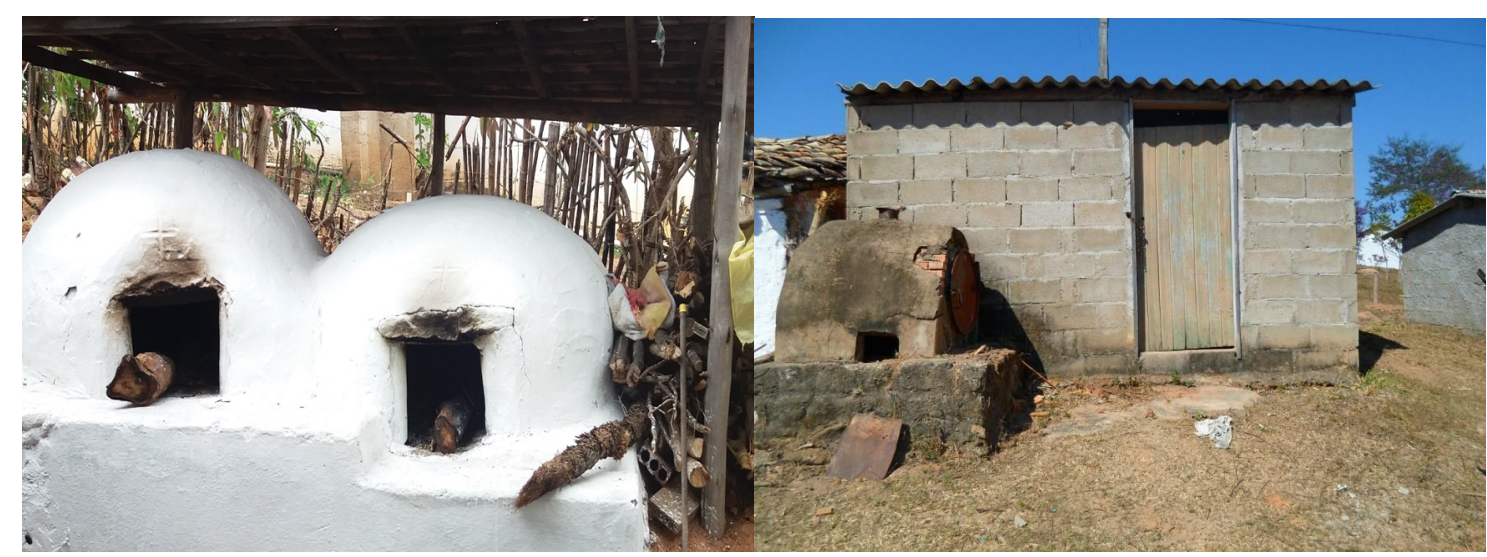

Figura 04 - Fornos, Cemitério do Peixe. Fonte: Fotografia do autor (18/08/2017)

Destaca-se, ainda, a questão da luz e da água. Conforme mencionado, o Cemitério do Peixe é um vilarejo no qual a maior parte das casas permanece desocupada o ano inteiro, recebendo mais de três mil devotos uma vez por ano. Muitas casas não possuem banheiro (embora isso esteja mudando nos últimos anos) e a "cozinha" é ao lado de fora, ao ar livre. Essas casas não possuem água encanada e eletricidade. A energia elétrica como um todo é fornecida por meio da Companhia Energética de Minas Gerais (Cemig), porém, nem todas as casas possuem o relógio instalado. Assim, aqueles que têm energia elétrica instalada "compartilham" com aqueles que não têm. Além disso, o Peixe conta com um banheiro público (com sanitários e chuveiro quente), e, para ter acesso aos mesmos, é preciso pagar uma taxa simbólica. Durante os dias de

Iluminuras, Porto Alegre, v. 20, n. 51, p. 323-347, dezembro, 2019. 
Festa, também costumam ser instalados (pela prefeitura de Conceição do Mato Dentro/MG) alguns poucos banheiros químicos. As pessoas inclusive fazem suas necessidades no mato e utilizam a água do rio. O Cemitério do Peixe fica situado à margem do Rio Paraúna, o qual fornece água para a higiene pessoal e, em certos casos, até para matar a sede e cozinhar, embora não seja totalmente despoluído.

No vilarejo do Cemitério do Peixe há algumas caixas de água canalizada nas nascentes, que, além de abastecerem a igreja, a casa paroquial, a casa dos romeiros e os banheiros, abastecem os devotos, que costumam buscar água diretamente nas caixas públicas, seja para o preparo dos alimentos, dentre outras coisas. As poucas casas que possuem água encanada fazem conexões entre a caixa de água pública e suas caixas de água particulares, através de canos e mangueiras, improvisados ou subterrâneos. Devido ao volume de pessoas durante os dias de Festa, a água da caixa pública costuma acabar, sendo necessário pedir às prefeituras das cidades mais próximas o envio de caminhõespipa. Diante disso, a água potável para higienizar os alimentos, cozinhar, lavar os utensílios e beber é relativamente escassa. Nesse sentido, destaca-se que, ao final dos quatro dias de Festa, o lugar fica bastante poluído em termos de copos, pratos e talheres descartáveis, dentre outros tipos de lixo.

No que tange ao compartilhamento e sociabilidade, segundo Van Gennep (2011), a comensalidade, ou rito de comer e beber em conjunto, é claramente um rito de agregação. Ao longo dos dias de Festa, observa-se a intensa interação social entre as pessoas. Todos estão em busca de socializar, conversar e se divertir. As pessoas estão sempre se ajudando e, normalmente, muito preocupadas em receber bem uns aos outros e aos visitantes. Como dito anteriormente, os primeiros a chegar são encarregados de preparar a casa para receber amigos e familiares. As pequenas casas são o centro de apoio e o elo familiar de dezenas de pessoas. Quando as pessoas chegam ao Peixe, buscam a casa de seus parentes e, em seguida, fazem uma verdadeira peregrinação entre as casas de outros familiares e amigos. Receber visitas e visitar faz parte dos rituais de socialização. Brandão (1980) afirma que a cultura camponesa tem como traço principal a necessidade de estar junto, de estar unido para fugir da solidão.

Nesse contexto, a vida é organizada em torno da família, dos vizinhos e dos grupos de interesse. A partilha é um elemento fundamental da vivência de uma cultura ruralizada. Na necessidade de socialização, a cortesia é um traço caracteristicamente

Iluminuras, Porto Alegre, v. 20, n. 51, p. 323-347, dezembro, 2019. 
notável de comportamento (SIMMEL, 1983). Apesar da existência de conflitos. Conforme observado por Simmel (1964), se todas as interações entre os homens é uma sociação, o conflito é uma das interações mais vivas, que não pode ser exercida por um indivíduo sozinho. Portanto o conflito é destinado a resolver dualismos divergentes, de certa forma, é uma maneira de conseguir algum tipo de unidade.

Durante o Jubileu de São Miguel e Almas, aqueles que são os anfitriões da casa se preocupam em receber a todos da melhor forma possível, e, assim, todos saem satisfeitos, comendo, bebendo e se divertindo. Enquanto nos mostrava os peixes defumados em cima do fogão à lenha, Maciel, por exemplo, ressaltou:

Olha os peixes aqui. Nós compra lá e traz pra fritá cá, né!? Quando minha mãe vai na Gouveia, ela já compra de uma vez, né!? Já compra e traz, porque, talvez a carne que ela traz não dá, né!? Aí ela tem que trazer um peixinho, um trem, pra, resistir o povo, né!? O povo chega caçando um trem. Um quer um cumê (comer/comida) aí, como é que você não põem um cumê? Por exemplo, você chega caçando um cumê, né?! Óh, pode você mesma vim cá servir, você mesma serve a comida, e como é que você não tem um pedaço de carne no cumê, né?! Aí é ruim, né?! (Maciel. vilarejo do Cemitério do Peixe, entrevista concedida em 18/08/2012).

O casal Rosário e Graciliano é frequentador do Peixe "desde a barriga da mãe", e, enquanto conversávamos, ela depenava uma galinha, alimento que foi ofertado aos padres que celebraram no Jubileu de 2012. De acordo com a Sra. Rosário, algumas famílias se sentem responsáveis por oferecer algum tipo de ajuda para a casa paroquial.

Assim, no decorrer do processo de interações sociais, a comida caracteriza-se por ser fator agregador e de importância central. Alimentar, fornecer e trocar alimentos compõem a solidariedade grupal vivenciada no Peixe. Representa uma dádiva, que vai sempre ser reproduzida. Como disse nosso interlocutor Maciel, como uma pessoa pode vir à sua casa e não encontrar algo para comer? Impossível! Ou mesmo, como disse a senhora Rosário, como não oferecer um alimento para os padres que veem de longe rezar por nós? Compartilhar o alimento, dentro da sua casa é, afinal de contas, a característica dessas communitas, nesse momento de liminaridade, que surge, senão, como expressão espontânea de sociabilidade, ao menos, como forma cultural e normativa - ao enfatizar a igualdade e o companheirismo como normas (TURNER,

Iluminuras, Porto Alegre, v. 20, n. 51, p. 323-347, dezembro, 2019. 
2008). O estabelecimento dessas relações possibilita a todos que formam esse grupo social sobreviverem e vivenciarem a Festa do Peixe.

Ao longo da pesquisa, era muito comum, e uma verdadeira obrigação também para nós, aceitar o convite para comer em todas as casas que entramos. Recusar a oferta de comer na casa de um mineiro, principalmente aquele ligado ao mundo rural, é uma grande ofensa. Não se recusa uma quitanda ${ }^{7}$, não se deixa de compartilhar o pão. A comida encontra-se sempre saborosa, servida com carinho e vontade pelos anfitriões. Da bebida alcoólica, principalmente a cachaça, às vezes consegue-se escapar, mas sempre havendo uma gozação: Como assim não vai tomar uma cachacinha? Não gosta ou não aguenta? Dizem sempre aos risos. Diante disso, por vezes, voltávamos para nosso acampamento, para descansar e, porque não dizer, “fazer a cesta”. Recordamos de um sábado que, antes das 13 horas, já havíamos tomado café da manhã em três casas e almoçado em outras duas casas. Sempre com muito café, biscoito, bolo, arroz, feijão, farinha, carne de porco, frango e muito mais. Se, não comer representa uma ofensa, não repetir é sinal de que a comida não foi do "agrado". Assim, muitas vezes, a comida acaba sendo servida em dobro.

Em seus estudos em torno da dádiva, Mauss (2003) destaca que a essência da reciprocidade está na natureza da coisa dada, na tríade dar, receber e retribuir, a qual cria vínculos entre almas, pois, de acordo com autor, a própria coisa tem uma alma, é uma alma, de onde resulta que dar alguma coisa a alguém é dar algo de si. Ao examinar etnografias sobre sociedades tradicionais, Mauss (2003) observou que as relações de troca não se davam exclusivamente a partir de bens e riquezas, bens móveis e imóveis, coisas úteis economicamente. Mas, constituíam-se, antes de tudo, como amabilidades, banquetes, ritos, danças, festas, feiras. Tais prestações e contraprestações se estabeleciam, segundo o autor, de uma forma "voluntária", por meio de regalos e presentes, embora, no fundo, fossem rigorosamente obrigatórias.

De modo semelhante, quando estamos no Cemitério do Peixe e observamos uma pessoa abrindo a sua casa, servindo comida e bebida, conversando e fazendo festa para

\footnotetext{
${ }^{7}$ Quitanda, do quimbundo Ki’tana, é o local onde se faz comércio (CUNHA, 1997). Nessa região do Estado de Minas Gerais, a palavra quitanda refere-se à pastelaria caseira, ou seja, os bolos, as rosquinhas, as broinhas, as broas, os biscoitos e os sequilhos (BONOMO, 2013). Sua origem provável está relacionada as negras de tabuleiro, que no ciclo do ouro e diamante, trabalhavam como vendedoras ambulantes, comercializando as mais diversas mercadorias, tais como bolos, doces, pastéis, biscoitos, mel, leite, frutas, aguardente (ROMEIRO; BOTELHO,2003).
} 
as visitas, ela está também estabelecendo uma relação de reciprocidade, uma relação que é, antes de tudo, estabelecida pela coletividade e não de forma individual. As pessoas que estão no Peixe compartilham códigos e normas, dentre as quais a maneira como se recebem os amigos, os familiares e as visitas, compondo o seu ethos social. O alimento e a hospitalidade que são oferecidos têm um valor simbólico, além da concordância daquele que recebe. Mauss (2003: 237) evidenciou que as dádivas circulavam na Melanésia e na Polinésia, com a certeza de que seriam retribuídas, "tendo como "garantia" a virtude da coisa dada, que é, ela própria, essa garantia". Desse modo, todos aqueles que, no Cemitério do Peixe, tratam uns aos outros com amabilidade e solidariedade, fazem dessa forma, pois acreditam que serão também tratados assim em outra oportunidade. Temos o reconhecimento de relações harmoniosas, afetuosas e criadoras de vínculos. Logo, uma obrigação de dar, receber e retribuir.

Com relação aos papéis de gênero, no que tange à comida, durante os dias da Festa do Cemitério do Peixe, nota-se a reprodução do cotidiano: dentre os devotos que usufruem de casas, as mulheres são as principais responsáveis pela organização da casa e pelo preparo da comida. Ao longo da Festa é possível observar as mulheres (sobretudo aquelas em condições socioeconômicas desfavorecidas) desempenhando essas funções e outras como buscar água na caixa de água comunitária e etc. Muitas dessas mulheres, sobretudo as mais jovens, durante as tarefas domésticas utilizam roupas velhas, touca protegendo os cabelos da fumaça do fogão, da gordura e da poeira, e, durante a noite, nos momentos da missa ou mesmo na parte profana da Festa, essas mulheres estão com os cabelos soltos, arrumadas e maquiadas. Já os homens, em muitas das casas em que entramos, estavam embriagados, dormindo, fora de casa socializando ou trabalhando, uma vez que alguns também realizam no lugar comércio de comidas e bebidas.

Abaixo (figura 05), por exemplo, podemos ver uma foto da década de 30, pertencente à família Ribas, da cidade de Gouveia. É possível observar vários homens bebendo e se divertindo ao fazer uma pose para a foto durante o Jubileu no Cemitério do Peixe. Como aponta Mintz (2001), a associação das mulheres com a comida e com o cozinhar; e dos homens com a caça e a vida pública; é um importante objeto de análise, com extensa literatura dedicada à comida e gênero (MINTZ, 2001). 


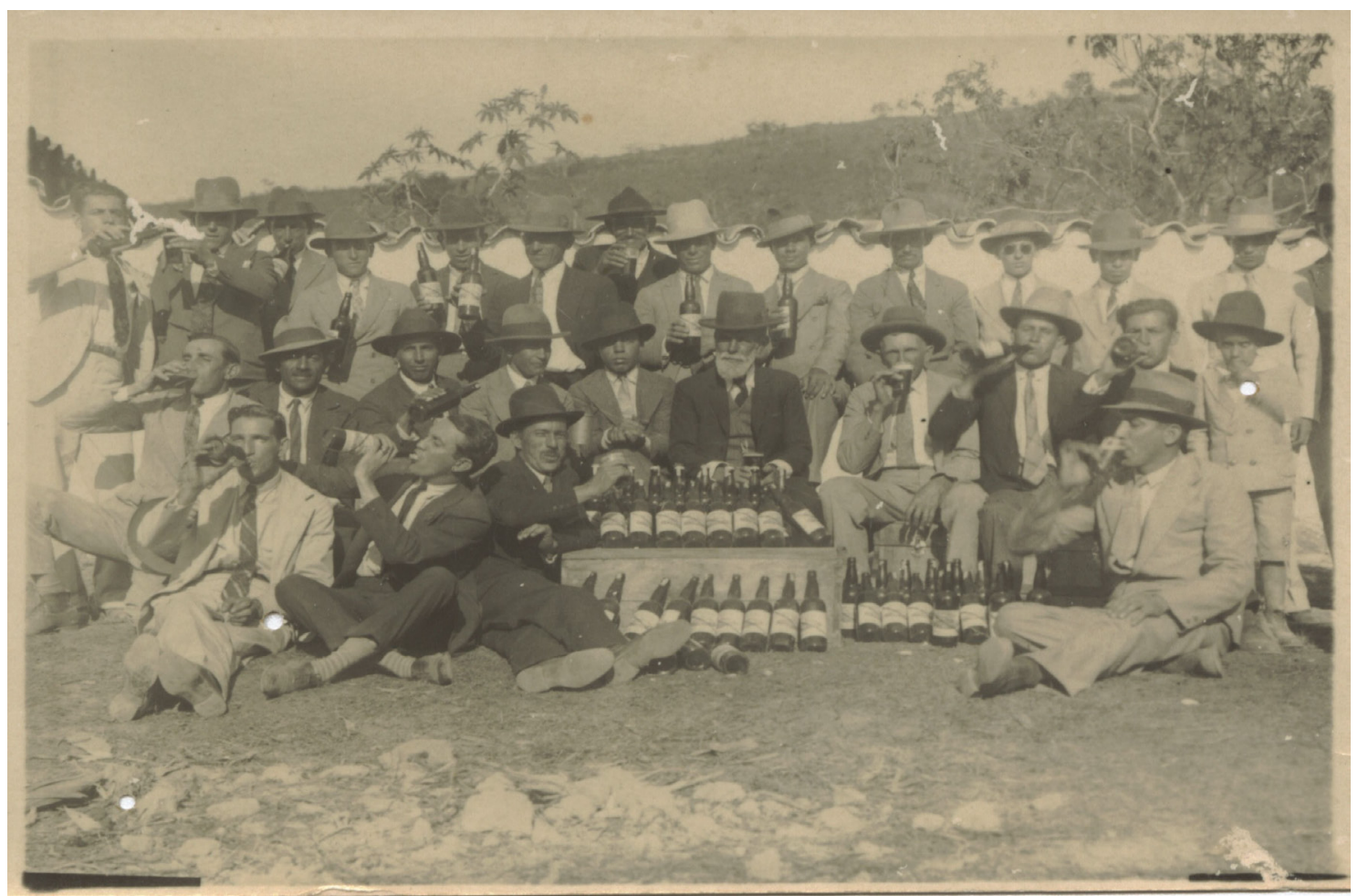

Figura 05 - Homens bebem e posam para foto (circa 1930), Cemitério do Peixe.

Fonte: Acervo da Família Ribas (Didico Ribas e Haroldo Ribas), fotografia cedida por Afrânio Gomes.

Quanto ao comércio, trocas materiais, capitalismo e consumo, durante o Jubileu, se concentram principalmente na Rua do Fogo e em seu entorno. Porém, existem também os vendedores ambulantes de produtos das fazendas da região, os quais normalmente passam no sábado oferecendo o produto que será entregue no dia seguinte, como rapadura, doce de leite e frutas, além do tradicional queijo minas e outros. No domingo, é possível encontrar esses vendedores próximos à igreja e ao Cemitério.

No que tange às tradições, especialmente aquelas relacionadas aos alimentos, destaca-se que a festa do Cemitério do Peixe é realizada em homenagem às Almas, consideradas "milagrosas", "santos de casa", "ancestrais a quem se recorre e agradece". Trata-se de um momento de agradecimento pela vida, pela saúde e pela prosperidade. Segundo Brandão (1987), o imaginário católico popular estabelece relações de interferência entre vivos e mortos; nesse sentido, destaca-se a tradição de agradecer às almas pela colheita farta e pedir prosperidade para a nova safra. No caso dos agradecimentos pela colheita farta, muitos devotos depositam ao pé do cruzeiro, localizado no centro do Cemitério do Peixe, punhados de milho, feijão, soja, algodão, lágrimas de nossa senhora, entre outras sementes, para agradecer pela fartura. Como

Iluminuras, Porto Alegre, v. 20, n. 51, p. 323-347, dezembro, 2019. 
ressalta Mintz (2001), a prosperidade nos faz esquecer o quanto à privação pode ser impositiva e, nesse sentido, os hábitos alimentares são veículos de profunda emoção.

No ano de 2018, bem como nos anos anteriores em que frequentamos a Festa, havia dentre as ofertas, as sementes crioulas - isto é, sementes produzidas por agricultores familiares e grupos tradicionais. Aqueles que pedem às Almas para ter uma boa colheita, ou mesmo, aqueles que precisam de sementes para um novo plantio, podem pegar essas sementes em troca de esmolas para as Almas. Assim, os devotos pegam as sementes deixando um valor simbólico, por exemplo, cinquenta centavos, na caixa depositada ao pé do cruzeiro. O dinheiro arrecadado durante o Jubileu, incluindo essa esmola, posteriormente é distribuído entre a Mitra, a Paróquia e também utilizado na manutenção da Festa, da Igreja e do Cemitério. Conforme nos disse Dona Anita, frequentadora e uma das principais organizadoras da Festa, juntamente com seu esposo Luís Rodrigues, o dinheiro arrecadado das doações sustenta o Jubileu. Por exemplo, no ano de 2013, o Jubileu arrecadou um total de $\mathrm{R} \$ 11.500,38$ ( $\mathrm{R} \$ 3.300$ das barracas, $\mathrm{R} \$ 6.365,15$ do cofre, $\mathrm{R} \$ 1.546,57$ da coleta e $\mathrm{R} \$ 288,66$ de donativos). As despesas em geral foram de $\mathrm{R} \$ 3.825,38$, mais os $12 \%$ da mitra e os $18 \%$ para a paróquia, gerando um saldo líquido de R \$ 5.3772,50 (TAVARES, 2014).

Logo, o pé do cruzeiro é um lugar de circulação e troca de sementes, de trocas entre os homens e desses com as Almas. $\mathrm{O}$ ato de depositar sementes ao pé do cruzeiro é uma ação simbólica e ritual de extrema importância. Mostra o vínculo e devoção às almas do Peixe, além de preservar o patrimônio cultural, o conhecimento local, os alimentos e as sementes de origem tradicional. Como nos disse Vânia e José Maria, frequentadores da Festa do Peixe, a oferta de sementes serve para:

As almas ajudar a correr tudo bem na plantação. Tipo, a sua roça está dando algum probleminha, pede às almas pra ajudar. Meu sogro deixa milho, deixa feijão, para não deixar faltar nada. Eles trocam a semente lá, eles pegam dos outros e os outros pegam deles, no pé do cruzeiro (Vânia Aparecida Ferreira. Costureira e frequentadora do Cemitério do Peixe, Gouveia - MG, entrevista concedida em 18/06/2019).

Desse modo, as sementes deixadas junto ao cruzeiro tornam-se protegidas pelas almas, sementes sagradas, tanto que, segundo os devotos, elas vingam de forma mais próspera: 
Tem semente, alho, feijão, você pega para plantar na terra, na sua horta. Pra poder bicho não estragar. Espanta todo inseto da terra. (José Maria, sineiro do Cemitério do Peixe. Gouveia - MG, entrevista concedida em 15/02/2019).

A troca de sementes e a oferta para as Almas também podem ser interpretadas a partir dos estudos em torno da dádiva (MAUSS, 2003). A dádiva não é desinteressada, porém é motivada primeiramente pelo interesse pelo outro, pelo reconhecimento do outro. Assim como nas prestações econômicas das sociedades tradicionais estudadas por Mauss, quando vemos os devotos das Almas do Peixe depositarem alimentos ao pé da cruz no interior do Cemitério, observamos que o objetivo dessas pessoas é estabelecer uma relação de reciprocidade com o transcendente. Espera-se que as Almas lembradas nas orações e nas doações, lembrem-se desses devotos posteriormente, garantindo a eles uma boa colheita e a proteção de toda a roça.

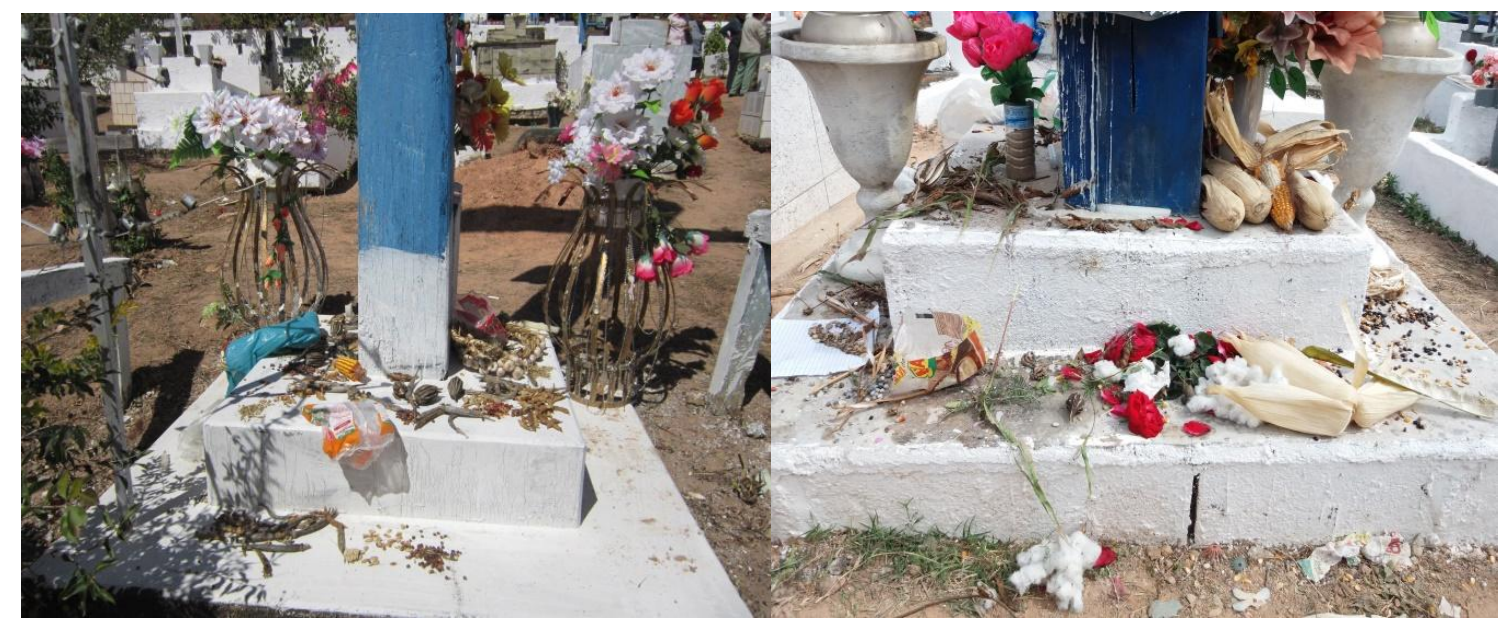

Figura 07 - Sementes ofertadas ao pé do cruzeiro, Cemitério do Peixe.

Fonte: Fotografia do autor (primeira foto: 18/08/2012; segunda foto: 19/08/2018).

Ao descrever e analisar aspectos relacionados à comida e ao ato de comer durante o Jubileu de São Miguel e Almas no Cemitério do Peixe, buscamos adotar alguns dos princípios abordados por Fabian (2013), no livro "O Tempo e o Outro", em que o autor problematiza o uso do Tempo na Antropologia, bem como o distanciamento do antropólogo do seu objeto de estudo, o "Outro". Assim, ao longo da pesquisa, buscamos uma relação coeva e dialógica entre o "pesquisador e o Outro". Uma vez que vivenciamos a Festa, assim como os devotos das Almas do Cemitério do Peixe, também estabelecemos relações sociais e de reciprocidade. Contamos e ouvimos histórias, criamos os nossos caminhos que, por vezes, se cruzaram com os caminhos dos Outros.

Iluminuras, Porto Alegre, v. 20, n. 51, p. 323-347, dezembro, 2019. 
Peregrinamos. Inclusive, precisamos nos preocupar com a viagem, onde vamos dormir e como vamos nos alimentar. Agenciamos e fomos agenciados, afetamos e fomos afetados. Os frequentadores do Peixe encontram-se no mesmo tempo em que nós pesquisadores. Conforme, Clifford (1998) a autoridade etnográfica se consolidou ao tornar-se mais sensível ao posicionamento do Outro.

\section{Considerações finais}

O objetivo desse trabalho foi descrever e analisar aspectos relacionados à comida e ao ato de comer durante o Jubileu de São Miguel e Almas no Cemitério do Peixe (MG), festa religiosa que acontece todos os anos, há mais de um século, durante o mês de agosto, atualmente, com duração de quatro dias. O lugar se destaca, pois o vilarejo nunca foi habitado constantemente, permanecendo vazio durante a maior parte do ano. Por isso, é chamado por alguns de "cidade fantasma". Porém, em torno do dia 15 de agosto, o local recebe milhares de pessoas, dentre devotos, romeiros, turistas, festeiros e comerciantes, que vão celebrar e festejar o Jubileu de São Miguel e Almas. Os dias de festividades reúnem pessoas de diferentes cidades mineiras. Durante o ápice do evento religioso, cerca de 4 a 5 mil pessoas passam pelo Cemitério do Peixe.

Frente a isso, através de métodos e caminhos propostos pela Antropologia, tais como a observação participante, entrevistas abertas e semiestruturadas, bem como a escrita etnográfica, foi possível descrever e analisar aspectos relacionados às práticas sociais e culturais em torno da comensalidade, desenvolvidas pelo grupo acompanhado, o qual representa uma parcela da população do interior de Minas Gerais. No que tange a Antropologia, destacamos o interesse constante dentro da disciplina pelas ações rituais e simbólicas presentes no ato de comer.

Desse modo, foi possível observar que a Festa acompanhada apresenta características aglutinadoras, possibilitando aqueles parentes e amigos que se dispersaram se reencontrarem no Peixe. Temos, então, um momento de fortalecimento da identidade e da memória do grupo natural da região. Durante a festividade, as comunidades locais promovem a preservação das tradições recebidas das gerações passadas, mantém seus laços umbilicais com o ambiente e o grupo social. A festa possibilita a preservação, reafirmação e ressignificação das práticas culturais locais, as 
quais foram construídas ao longo do tempo. O Jubileu de São Miguel e Almas, enquanto um bem cultural possibilita à efervescência religiosa, a reprodução de práticas sociais, a transmissão de conhecimento entre as diferentes gerações e a afirmação de uma memória coletiva.

Muitos dos frequentadores do Peixe continuam a reproduzir as práticas sociais e culturais de seus pais e avós, mesmo que, por vezes, resignificando-as de acordo com o seu tempo. Dentre essas práticas, destacamos ao longo do artigo, aquelas em torno da alimentação. Nota-se, assim, que no desenrolar do processo de interações sociais, a comida caracteriza-se por ser fator agregador e de importância central para o grupo. Alimentar, fornecer e trocar alimentos compõem a solidariedade grupal vivenciada no Peixe. Representa uma dádiva, que vai sempre ser reproduzida.

Dentre os códigos e normas estabelecidos, destaca-se o reconhecimento de relações harmoniosas e afetuosas, com a criação de vínculos, os quais geram uma obrigação social. Além do mais, essa obrigação também é encontrada na tradição religiosa de ofertar alimentos às almas. No laço determinado entre os fiéis e às Almas do Peixe, notam-se relações de reciprocidade estabelecidas entre esses. O alimento, símbolo do milagre e do agradecimento, encontra-se na tríade dar, receber e retribuir: os devotos, tradicionalmente, fazem pedidos, através das rezas e da oferta dos alimentos. As Almas, por sua vez, realizam os milagres. Por fim, os devotos agradecem retribuindo com mais orações e alimentos, fazendo novos pedidos, ad infinitum.

\section{REFERÊNCIAS}

ABDALA, Mônica C. Sabores da tradição. Revista do Arquivo Público Mineiro, Belo Horizonte, Ano XLII, no 2, p. 119-129, dez. 2006.

BAKHTIN, Mikhail. A cultura Popular na Idade Média e no Renascimento. O contexto de François Rabelais. São Paulo: HUCITEC, 2010.

BONOMO, Juliana R. A culinária mineira como signo e patrimônio cultural imaterial. Anais, II CONINTER - Congresso Internacional Interdisciplinar em Sociais e Humanidades. Belo Horizonte, de 8 a 11 de outubro de 2013. Disponível em $<$ https://pt.scribd.com/document/306462568/A-Culinaria-Mineira-Como-Signo-ePatrimonio-Cultural>. Acesso em 10/07/19.

BRANDÃO, Carlos R. Os Deuses do Povo: um estudo sobre a religião popular. São Paulo: Editora Brasiliense, 1980. 

1987. . O festim dos bruxos: estudos sobre a religião no Brasil. São Paulo: Editora Ícone.

BURTON, Richard F. Viagens aos planaltos do Brasil. Tomo II. tradução de Américo Jacobina Lacombe. - 2. ed. - São Paulo: Companhia Editora Nacional. 1983.

CANESQUI, Ana Maria. Comentários sobre os Estudos Antropológicos da Alimentação. In: CANESQUI, Ana Maria; GARCIA, Rosa Wanda Diez Garcia (Org.). Antropologia e nutrição: um diálogo possível [online]. Rio de Janeiro: Editora FIOCRUZ, 2005, pp. 23 47. 216. 1988. Antropologia e alimentação. Revista de Saúde Pública, v. 22, n. 3: 207-

CARRARA, Ângelo A. O Distrito dos Diamantes, 1734-1757. Juiz de Fora: Clio Edições, 2017.

CLIFFORD, James. Sobre a autoridade etnográfica. In: CLIFFORD, James. A experiência etnográfica: antropologia e literatura no século XX. Rio de Janeiro: Ed. UFRJ, 1998.

CONTRERAS, Jesús; GRACIA, Mabel. Alimentação, sociedade e cultura. Rio de Janeiro: Editora Fiocruz, 2015.

CUNHA, Antônio G. Dicionário Etimológico Nova Fronteira da Língua Portuguesa. Rio de Janeiro: Editora Nova Fronteira, 1997.

DA MATTA, Roberto. O que faz o Brasil, Brasil? Rio de Janeiro: Rocco, 1986.

DUTRA, Rogéria C. A. Ambiente, práticas culinárias tradicionais e saberes locais: o caso das quitandas na Serra da Mantiqueira, MG. XI Reunião de Antropologia do Mercosul. 2015. 1-15. Disponível em: $<$ http://xiram.com.uy/ponencias/GT83/Rog\%C3\%A9ria\%20Campos\%20de\%20Almeida\%20Dutra_\%20Ambiente,\%20praticas $\% 20$ culin $\%$ C3\%A1rias $\% 20$ tradicionais $\% 20 \mathrm{e} \% 20$ saberes $\% 20 \% 20$ locais$\% 20 \mathrm{o} \% 20$ caso $\% 20 \% 20$ das $\% 20$ quitandas $\% 20$ na $\% 20$ Serra $\% 20 \mathrm{da} \% 20$ Mantiqueira, $\% 20 \mathrm{MG}$. pdf $\gg>$. Acesso em: 03 jun. 2019.

FABIAN, Johannes. O Tempo e o Outro: Como a Antropologia estabelece seu objeto. Rio de Janeiro: Editora Vozes, 2013.

GENNEP, Arnold Van. Os ritos de passagem. 3 ed. Petrópolis: Vozes, 2011.

INGOLD, Tim. Estar vivo: Ensaios sobre movimento, conhecimento e descrição. São Paulo: Vozes, 2015.

MAUSS, Marcel. Sociologia e antropologia. São Paulo: Cosac \& Naify, 2003.

MINTZ, Sidney. Comida e Alimentação: Uma breve revisão. Revista Brasileira de Ciências Sociais, vol. 16, n.47, out. 2001. Disponível em:

$<$ http://www.scielo.br/scielo.php?script=sci_arttext\&pid=S0102-69092001000300002> Acesso em 10 jul 2019. 
MOREIRA, Sueli A. Alimentação e comensalidade: aspectos históricos e antropológicos. São Paulo, v. 62, n. 4, out. 2010. Disponível em:

http://cienciaecultura.bvs.br/scielo.php?script=sci_arttext\&pid=S0009-67252010000400009 Acesso em: 01 jul 2018

OBSERVADOR, O Callado. Publicações à Pedido. Jornal O Jequitinhonha, Diamantina. 16 nov. 1861. Ed. 40, pp. 2. Disponível em: $<$ http://memoria.bn.br/hdb/periodico.aspx $>$. Acesso em: 20 set. 2018.

PEREZ, Léa F. Antropologia da efervescência coletiva. In: PASSOS, Mauro (Org.) A festa na vida: significados e imagens. Petrópolis: Vozes, 2002.

ROMEIRO, Adriana; BOTELHO, Angela. Dicionário histórico das Minas Gerais: periodo colonial. Belo Horizonte: Autêntica, 2003.

SIMMEL, Georg. Sociabilidade - um exemplo de sociologia pura e formal. In: MORAES FILHO, Evaristo de (Org.) Sociologia. São Paulo: Editora Ática, 1983.

.SIMMEL, Georg, O conflito como sociação. (1964) (Tradução de Mauro

Guilherme Pinheiro Koury). RBSE - Revista Brasileira de Sociologia da Emoção, v. 10, n. 30, pp. 568-573. Disponível em: $<$ http://www.cchla.ufpb.br/rbse/SimmelTrad.pdf $>$ Acesso em: 05 mar 2018.

TAVARES, Thiago Rodrigues. Rituais funerários no Vale do Jequitinhonha: a vivência popular do catolicismo e as transformações nas atitudes dos homens frente a morte. Dissertação (mestrado em Ciência da Religião), Universidade Federal de Juiz de Fora, Juiz de Fora, 2014.

. O Cemitério do Peixe e as Missões Redentoristas. In: Catolicismo(s) ontem, hoje e sempre...? Interfaces com o tempo, sociedade e cultura. ARCHANJO DE ALMEIDA, R.; DA VEIGA, A. C.; DE ARAÚJO PORTES, A. L.; DE SOUSA CARVALHO, N.; MANGEA DA SILVA, L. F.; TAVARES, T R..; COSTA LOPES, A.; LACERDA SIMÕES DUARTE, F.; BONTEMPO REIS, M.; DE OLIVEIRA LUPION, M. R. SACRILEGENS, v. 15, n. 2, jul/dez 2018. p. 73-86.

TOMBO, Livro de Tombo. Paróquia de Santo Antônio de Gouveia. Arquidiocese de Diamantina: Gouveia-MG. $n^{\circ}$. 03, folha 08. 1976.

TURNER, Victor. O processo ritual. Petrópolis: Vozes, 1974. . Dramas, Campos e Metáforas: Ação simbólica na sociedade humana. Niterói:

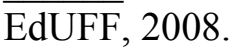

